\title{
The Clerical Republic (Farská republika)
}

\author{
Author: Dominik Tatarka
}

First Published: 1948

Translations: Czech (Farská republika, 1949; new translation 1961); Hungarian (A plébános köztársasága, 1951; new translation Reverendás köztársaság, 1997); German (Die Pfaffenrepublik, 1960); Ukrainian (Popivska respublika, 1961); Russian (Respublika popov, 1966).

About the Author: Dominik Tatarka (1913-1989) was born in Drienové in the Kysuce region of North-Western Slovakia into a large family of peasants. His father was killed in World War I, his mother had to take care of him and his five sisters alone. He studied French and Czech philology at Charles University in Prague and at Sorbonne in Paris (1934-1939). During World War II he taught in high schools in Žilina (19391941) and Martin (1941-1944). In 1944 Tatarka became a member of the Communist Party and took part in the Slovak National Uprising against Nazi Germany. After the war he worked as a journalist and as a scriptwriter. His works often reflect his personal experiences. His first pieces of prose were influenced by surrealism and the avantgarde. Tatarka translated French works (Musset, Maupassant and Vercors) into Slovak. In 1956, he wrote a satirical short story The Demon of Conformism against Stalinism (it was published in the journal Kultúrny život in 1956, but it couldn't be edited into a book until 1963). Tatarka protested against the Warsaw Pact occupation of Czechoslovakia in 1968 and resigned from membership in the Communist Party. In the 1970s and 1980s he was persecuted by the Communist regime, banned from public life and not allowed to publish anymore. From 1970 he worked as a forest worker. Later he lived as a permanently disabled pensioner, his works were edited only in samizdat or exiled publishing houses. He was one of the few Slovak signatories of Charter 77. In October 1987 he was the first to sign Charter's Declaration on the deportation of Jews from Slovakia (to the 45th anniversary of the deportations organised by the Slovak government).

Further Important Publications: Panna Zázračnica (1942, The Miraculous Virgin; novella); Démon súhlasu (1963, The Demon of Conformism; satirical short stories); Prútené kreslá (1963, Wicker Armchairs; prose); Proti démonom (1968, Against the Demons; essays); Písačky (samizdat 1979, Köln 1984, Scribbles; reflections, reports and letters); Sám proti noci (in the Czech translation, München 1984, Alone Against the Night; reflections); Navrávačky (samizdat 1987, Köln 1988, Recordings; memoir). 


\section{Content and Interpretation}

The story is set in Žilina, a town in North-Western Slovakia, and its surroundings in the years between 1939 and 1941. These years are the first of the Slovak clerofascist republic that is mentioned in the title of the novel. The main character is Tomáš Menkina, a young teacher who has some of the features to be found in the author's autobiography.

Tomáš came from a nearby village. His father died when Tomáš was a child. Fortunately, they had an uncle in the U. S., John Menkina, who supported the family and paid for Tomáš' studies.

The plot of the novel begins at the moment when John Menkina returns home from America after several decades. At the same time Tomáš returns from his military service in Poland where the Slovak army has helped the Germans in the war against the Poles. Neither of them likes the governing of Slovak clerofascist and national regime, an ally of Hitler's Germany, that persecutes leftist intellectuals, and workers as well as Jews.

The director of the high school where Tomáš teaches, Belo Kovál', a coward and a hypocrite, enforces the clerofascist ideology. Tomáš and his colleagues, Darina Introbusová, a daughter of the Lutheran pastor, and Fraňo Lašut, "a quarter Jew”, all have intense feelings of disgust and annoyance. Tomáš admires Darina, but he sleeps with the publican's wife Achinka. Fraňo decides to save a Jewish girl Edita Soláni from persecution and convinces Darina's father to falsify her baptismal letter. Fraňo wants to marry her, but they are revealed. All the names of the baptised Jews are in the newspapers and the pastor is arrested. Tomáš revolts against the obligatory visit to the church, spiritual exercises and confession.

The real change in Tomáš' life and persuasion comes as a result of his later imprisonment. He unknowingly carried suitcases with leaflets which had been given to him by his Communist friend Lyčka. He is detained. Tomáš' mother, a pious and simple Christian woman, wants to help him and visits a Roman Catholic priest named Jozef Tiso, who is also the Slovak president, with pleading for mercy. Tiso orders a rigorous investigation, and so she has harmed her son. Tomáš is strictly interrogated and maltreated, because the police chiefs are convinced he is a member of the Communist resistance. He spends ten months in prison. As a consequence of this, Tomáš becomes a conscious communist and a regime opponent.

At the same time, Tomáš' uncle John Menkina on the contrary changes into a conformist. He "aryanises" the hotel and the pub which were confiscated from Jewish owners, and hosts agents of the Fascist regime there. Returning from prison, Tomáš separates from his mother and his uncle. Hitler's war against the Soviet Union breaks out and the Slovak army, as one of Germany's allies, takes part in it. Tomáš receives his orders and departs to the front.

The first version of The Clerical Republic was written during the war (Olonovová, 1993, p. 300). In the early 1950s, when Stalinist communists established the doctrine of socialist realism, Tatarka was criticized for "naturalism" and "underestimation of 
the role of Communist Party" in this novel. He was forced to eliminate some scenes of sexual intercourse between Tomáš and Achinka (Petrík, 2013).

The novel depicts real historical characters and places, brings autobiographical motifs (see above) but is also fictive. Some characters are ironized and caricatured (the Slovak president and priest Jozef Tiso, director of the school and military guards).

The novel utilises modernist and avant-garde devices. The plot is not presented in traditionally realistic narration, but in hints, abbreviations, metaphors using fantastic and imaginative scenes. For instance, in scenes in the prison violence and brutality are not broadly described but only indicated in some small details (Hudymač, 2008). Or the Communist orientation of the workers is suggested by the red colour on the dirt on their fingernails (Tatarka, 1948, p. 173) and the red signs marking the trails in the mountains (p. 248).

\section{Main Topics and Problems}

Motifs of disgust, depression, nausea and annoyance as well as "hygienic love" (Tomáš' relationship with Achinka was only physical) might be inspired by the famous works of French literary existentialists, J. P. Sartre's novel La Nausée (1939, Nausea) or by Albert Camus's novel L'Étranger (1942, The Stranger). The language of ideology in periodicals, radio or politicians' speeches is depicted in snippets, like in modernist collages. It also concerns official antisemitic propaganda: the "radical solution to the Jewish question in Slovakia, Jews were removed from public services [...] the end of international Jewish Bolshevism [...] the Jew will always remain a Jew” etc. (Tatarka, 1948, pp. 127, 132 and 135).

Jewish characters play an important role in the novel. After anti-Jewish laws were enacted, most of them are outsiders in society. They are "people without a future" living in the "bubble" (p. 125). Some of them resign themselves and accept their fate, for instance the old married couple Klapovecs, whose hotel and café are expropriated, "aryanised" by John Malkina. They are happy to have a small room in their former big house. Or Edita Solani's father who is a stonemason. His shop is painted with tar and he gives up his job.

Other Jews try to save themselves. The old Jewish attorney Werner offers John Malkina a large sum for his American passport which is a guarantee of freedom. The rich family of the former factory director Friedmann converts to Lutheranism. Edita hopes to be rescued through a false confirmation of baptism and marriage to Fraňo Lašut. See Jašík's $\rightarrow$ St. Elizabeth's Square. She jokes with Fraňo about her large Jewish nose. But at the same time, she undergoes plastic surgery for fear of being found out. The narrator describes the result as a grotesque scene. Later, Edita, a former student of medicine, moves to Bratislava. She works in a pharmacy and is involved in the resistance.

On the other hand, Slovak Roman Catholic nationalists and officers of the Hlinka Guard (the Slovak military Fascist organisation) proclaim their struggle against the Jews. But actually they use their services and want to get their property. 


\section{Cited Works}

Olonovová, E. (1993). Poetika prózy Dominika Tatarky. Česká literatura, 39(3), pp. 292-315. Patera, L. (1994). Tvorba Dominika Tatarky ve společenském a literárním kontextu. Slovenské rozhlady, 1(1-2), pp. 29-42. Petrík, V. (2013). Tatarkove autorské zásahy do románu Farská republika. In: I. Pospíšil, A. Zelenková, eds., Dominik Tatarka v souvislostech světové kultury. Brno: Česká asociace slavistů, pp. 99-104. Tatarka, D. (1948). Farská republika. Martin: Matica slovenská.

\section{Further References}

Antošová, M. (2011). Tatarkovo dielo v kontexte existencializmu. Nitra: Univerzita Konštantína Filozofa. Bombíková, P. (2000). Nové formulovanie spisovatela a spisovatel'skej práce v rokoch 1946-1956: Prípad Dominika Tatarku. Slovenská literatúra, 47(3), pp. 100-118. Hudymač, M. (2005). Dominik Tatarka: Farská republika. Available at: http://pisacky.blogspot.com/2008/08/dominik-tatarka-farsk-republika.html [Accessed: 04.04.2019]. Hamada, M. (1994). Tatarkova Farská republika a súčasnost'. In: J. Borgulová, ed., Literatúra a Slovenské národne povstanie. Banská Bystrica: Literárne a hudobné múzeum v Banskej Bystrici, pp. 47-52. Jančovič, I. (1996). Dominik Tatarka a jeho dielo v premenách času: 1940-1956. Banská Bystrica: Metodické centrum. Liehm, A. J. (1970). The Politics of Culture. New York: Grove Press. Mikula, V. (2010). Démoni súhlasu i nesúhlasu. Ivanka při Dunaji: F.R.\&G. Višňovský, J. (2009). Život a dielo Dominika Tatarku. Trnava: Univerzita sv. Cyrila a Metoda. Vydra, A., Zajac, P. (2018). Pokušenia Dominika Tatarku. Bratislava: W Press. 